\title{
Do contemplative practices in school curriculum help elementary school children become more civic-mindedness?
}

\author{
Chusri Sattayanont, King Mongkut's University of Technology Thonburi ,Thailand, \\ chusri.bb@mail.kmutt.ac.th, ORCID:0000-0002-6515-046x \\ Jariya Neanchaleay, King Mongkut's University of Technology Thonburi,Thailand,Jariya.nea@kmutt.ac.th \\ Saranya Chuathong, King Mongkut's University of Technology Thonburi, \\ Thailand,Saranya.chu@kmutt.ac.th
}

\begin{abstract}
This study investigated the influence of contemplative curricular experiences on civic-minded among elementary school children in Thailand. The research was separated into 2 phases. In phase 1, the 725 students (children) gave their opinion with survey responses about civic-mindedness. In phase 2 , the researchers investigated the transformative educational experiences with contemplative practices (e.g., mindfulness, meditation, and yoga) for 125 elementary school children from grades 4-6 in private schools in Thailand. Significant changes was found in civic-minded "awareness", "motivation", and "behavior" among children after a year of contemplative educational experiences in school. Boys reported significantly more change in civic-minded "behavior" than girls. The cultivation of civic learning among children was the implications of findings. The development of civic-mindedness is a major goal of schooling in Thailand. Contemplative practices help to develop social consciousness and a sense of responsibility toward each other and the community.
\end{abstract}

Keywords: Civic mindedness, Contemplative practices, Mindfulness.

Received: 08.11.2020 Accepted: 19.12.2020 Published: 26.01.2021

\section{INTRODUCTION}

Elementary education in Thailand is the foundation of the whole educational system. It is also compulsory education that is required by every citizen. It is the education that aims to enrich children's multi-faceted development, with an emphasis on reading and writing ability, cultivating morality, life skills, and both thinking and problem-solving abilities, according to their personal needs. The improvement of the quality of education should be the most important and challenging task. In today's world, with the rapid changes of technological advancements, to prepare Thai students for the $21^{\text {st }}$ century, educators must make them globally literate. Many issues related to global and international studies are missing. Certainly, with the requirement for all schools to implement the National Curriculum, developmental change is a process with which all schools must come to terms. Much of that which has gone before can be treated as a learning process; one on which the requirements for the future can build. This is the critical issues; society needs schools to reinforce about the soft skills or citizenship education as a social and emotional learning.

The development of civic-mindedness is the major goal of schooling in Thailand, that should be appropriate for developing ethical reasons and keep fostered in Elementary curriculum because it is the suitable age. The teachers can promote and enabling them to understanding, perception towards criteria and have the reasonable thinking abilities. There was an urgent need for students in the Elementary education level to be equipped with the contemplative curriculum to create more awareness and preparedness for the changing society. The relevance of the contemplative curriculum was inevitable due to the serious socioeconomic problems that have plagued the country in recent times. (Srijumnong, S., Sri-ampai, P, and Chano, J., 2015; Phanthumnavin, D., 2001 cited in Tewanarumitkun,P.,2012; Kohlberg,1976 cited in Goldstein,S. and Naglieri,JA. 2010; Piaget and Inhelder, 1969 cited in Gardner,H.,2011).

Contemplative Education attempts to foster the development of experiential, contemplative, and mindful inquiry in curriculum and pedagogy. In addition to addressing the social and emotional needs of contemporary college students as factors that inform their intellectual growth, contemplative pedagogy also addresses the needs of the teacher to be fully engaged in the process of connected knowledge and teaching that takes place in the learning exchange. Contemplative pedagogy relies, therefore, on a conception of mindful teaching as a process through which teachers struggle to attain congruence, integrity, and efficacy in their practice (Fullan, M.,2015). Contemplative practices can be introduced in a secular fashion, as is typically the case in clinical or educational contexts (e.g., Baer, 2003 at cited in Amanda et al., 2014 ; Burke, 2010; McCown,D., 2013). Buddhist contemplative practices at their core involve the 
regulation of attention. In addition, these practices often focus on the cultivation of prosocial attitudes and behavior, such as compassion, empathy, and respect for others. They reflect a system of values and have moral implications. Contemplative Education must include the study of the students' perceptions in order to enhance and develop conscious awareness. It is about developing the students' progress by means of various techniques. These techniques are based on individual aptitude. They focus on both the students' creativity and free expression (e.g., mindfulness, meditation, and yoga). This is emphasized in some schools to develop social consciousness, and a sense of responsibility toward each other and the community.

This study investigated the influence of contemplative curricular experiences on civic-minded "awareness", "motivation", and "behavior" among elementary school children in Thailand. The research was separated into 2 phases. In phase 1, the 725 students (children) gave their opinion with survey responses about civic-mindedness. They were informed that their survey responses would be completely confidential and would not be linked to their identities. In phase 2, the researchers investigated the transformative educational experiences with contemplative practices (e.g., mindfulness, meditation, and yoga) for 125 elementary school children from grades 4-6 in public and private schools in Thailand.

\section{BACKGROUND}

Civic mindedness is the features in psychological theories about personality development and human development over the lifespan, and in sociological theories about the ways in with individuals fit into and influence their wider society. It was compared as feeling and thinking as the mutual owners towards public things as well as the use of rights and duties to supervise and maintain public things together. It may take various forms as a community responsibility involves positive actions and behaviors that are intentional and voluntary. (Phanthumnavin, D., 2007 cited in Tewanarumitkun, P.,2012;Rakmanee,S.,2018;Wisalo,P.,2018, Eisenberg.et.al., 2015).Fostering consciousness in people to be responsible for themselves and society will help to foster morality and ethics in people, especially in children and adolescents. This is considered to be something that is generated internally among people. " Civic-mindedness" is important in fostering consciousness in people to learn to sacrifice, unite, and cooperate for public benefits. Civic-mindedness should be fostered in childhood because it is the age that is sensitive to growth and reinforces ethics and culture. Based on the theory of ethical reasoning development and theory of intellectual development, they have consistent results that childhood is appropriate for developing civic-mindedness of students and facilitating through study, research, survey, and inspection from actual situations that provide an understanding of civic-mindedness (Phanthumnavin,D.,2001 cited in Tewanarumitkun,P.,2012; Kohlberg, 1976 cited in Goldstein,S. and Naglieri,JA.2010 ; Piaget and Inhelder, 1969 cited in Gardner,H.,2011). Based on earlier research findings, it could be expected that child-specific factors such as school adjustment, social skills such as empathy and responsibility and family attachment will contribute to the development of civic mindedness, as will aspects of the family environment.

This study investigated the following questions:

1) How is the influence of contemplative curricular experiences on civic-minded "awareness", "motivation", and "behavior" among elementary school children in Thailand?

2) What is the correlation among students' awareness, motivation and behavior among elementary school children in Thailand?

\section{METHODS}

The study was conducted as a mixed methods design in the quantitative and qualitative model. In this design, data were collected in a variety ways via multi-instrument approach.

\section{Participants}

The participants in this study were separated into two phases, the first one, the researchers used a sample of 725 students enrolled in an elementary school in Thailand. In the process of data collection, researchers are obligated to inform the study participants about the purpose of the study and guarantee that the result does not affect their individual identities. In phase two, the researchers investigated the transformative educational experiences of 125 The cultivation of civic learning among children was the implications of findings. elementary school children for grade 4-6 in public and private schools in Thailand.

\section{Measures}

The questionnaire survey was conducted in Thai version; it assessed civic-minded "awareness", civicminded "motivation" and civic-minded "behavior" (Table 1). 
Civic-minded "awareness". This section on students' awareness assesses the knowledge that something exists or understanding of a situation or subject at the present time based on information or experience. The content of the items in our Thai survey reflects the content of items on the scale developed. Their scale measured endorsement of acquisition, the placement of possessions (e.g. 'I will always be helping each other), acquisition as the pursuit of empathy (e.g. 'I felt uncomfortable when seeing friends scrawling the wall or damaging the public domain), and possession of the responsibility (e.g. 'I use resources economically, even I know that they have enough for everybody') (Table 1). (Mick DG.et, al., 2012 ; Valdez, 2020 ). A total of all items were constructed, the 5-point Likert-Scale denoted 1 for strongly disagree, 2 for disagree, 3 for unsure, 4 for agree and 5 for strongly agree.

Civic-minded "motivation". This section on students' motivation assess the enthusiasm, need or reason for doing something (Cambridge,2019). The content of the items in our Thai survey reflects the content of items in the scale measured cause of willingness (e.g. 'I help others because it makes me happy'). All students were asked to respond to 10 questions concerning the domain of motivation by indicating on a 5-point Likert-Scale ( 1 for strongly disagree, 2 for disagree, 3 for unsure, 4 for agree and 5 for strongly agree).

Civic-minded "behavior". This section on students' behavior assess the particular behavior regarding civic-mindedness. 10 items scale was used to assess the tendency to act in a visibly civic-minded way themselves in the scale measured behavior apparently (e.g. 'I take care of all books and puts them back to place after finished reading'). Students were asked to respond to each item using the 5-point Likert-Scale ( 1 for strongly disagree, 2 for disagree, 3 for unsure, 4 for agree and 5 for strongly agree).

\section{Validity and Reliability}

In order to ensure validity in the study, content validity were checked by 3 experts and they were complete at IOC $>=0.8$ by items and 0.95 by overall. For the reliability calculation of the study, Cronbach alpha reliability coefficients of the whole questionnaire were accepted as reliable with $91 \%$ compliance.

\section{Analysis}

The researchers used two methods for the collection of data to ensure the validity and reliability of the assessment: (1) peer acceptance and use of the assessment tools; and (2) comparison of the tool against theoretical constructs for support of the items being measured. The composition of each instrument used in this study was based on items from established tools for measuring students' awareness, students' motivation and students' behavior. Our survey questions were created for a Thai context using a standard research technique of translation/back-translation ( Behling\&Law,2000 cited in Thomas, 2017). Questions were initially developed in English. Two bilingual Thai researchers then translated each item into Thai. Two bilingual researchers and the principal researcher reviewed each item written in Thai and translated it back into English. Finally, the English and Thai translations were compared, and, by consensus of the research team, found to be conceptually equivalent. Tables 1 and 2 present items and reliability estimates for each measurement scale.

\section{RESULTS}

The descriptive statistics results section was separated into two parts. For the first study, the researchers used a sample of 725 students to establish the reliability and validity of a public mindedness. In the second study, the researchers used the contemplative practice curriculum to enhance civic-mindedness education for elementary students among 125 students in the elementary grades 4-6. Civic-mindedness education had been proposed to consist of three components: Students' Awareness, Students' Motivation, and Students' Behavior. Instruments, appropriately modified to refer to the civic-mindedness (ten items each for Students' Awareness, Students' Motivation, and Students' Behavior). The items used a five-choice Likert-Scale, which asked respondents to select a number ( $5=$ strongly agree to $1=$ strongly disagree) to indicate their level of agreement with each statement.

Table 1. Result of Factor Analysis Civic minded "awareness", "motivation", and "behavior": Factor loadings with varimax rotation $(N=725)$

\begin{tabular}{|l|c|}
\hline Scale & Loadings \\
\hline Civic minded "awareness" (Alpha =.791) & Factor \\
\hline 1. I will always help each other. & .489 \\
\hline $\begin{array}{l}\text { 2. I felt uncomfortable when seeing friends scribble writing on the wall or } \\
\text { damage the public domain. }\end{array}$ & .419 \\
\hline
\end{tabular}




\begin{tabular}{|c|c|}
\hline Scale & Loadings \\
\hline $\begin{array}{l}\text { 3. In my opinion, society's problem needs to be solved and it is necessary } \\
\text { to get the cooperation from everyone in society. }\end{array}$ & .423 \\
\hline 4. I think that environmental conservation is my duty. & .384 \\
\hline 5. I am patient and have respect for other members' rights. & .484 \\
\hline $\begin{array}{l}\text { 6. I use resources economically, even though I know that there is enough } \\
\text { for everyone. }\end{array}$ & .564 \\
\hline 7. I help to maintain public facilities duty. & .410 \\
\hline $\begin{array}{l}\text { 8. I am an active member of society and I will be do everything that I can } \\
\text { do to respect it. }\end{array}$ & .495 \\
\hline 9. I do not make people miserable. & .500 \\
\hline 10. I think my actions are a part of making the happy society. & .354 \\
\hline \multicolumn{2}{|l|}{ Civic minded "motivation" (Alpha $=.838)$} \\
\hline 1. I help others because it makes me happy. & .547 \\
\hline 2. I help others because it makes my parents proud of me. & .480 \\
\hline 3. I help others because it makes my teacher appreciative. & .650 \\
\hline $\begin{array}{l}\text { 4. I help others because I think that when I need help, I will get help in } \\
\text { return another. }\end{array}$ & .419 \\
\hline 5. I help others because it makes me feel loved by my friends. & .556 \\
\hline 6. I help others unconditionally. & .463 \\
\hline 7. I help others because they need help. & .606 \\
\hline 8. I help others because I will feel accepted. & .640 \\
\hline 9. I help others because it will add value to my life. & .518 \\
\hline 10. I help others because I believe that it's part of my success. & .447 \\
\hline \multicolumn{2}{|l|}{ Civic minded "behavior" (Alpha $=.811)$} \\
\hline 1. I tidy up my belongings after I am finished using them. & .305 \\
\hline $\begin{array}{l}\text { 2. I take care of all books and return them to their places after I am } \\
\text { finished using them. }\end{array}$ & .465 \\
\hline $\begin{array}{l}\text { 3. I do not write/draw on the walls, nor destroy properties around the } \\
\text { house and school. }\end{array}$ & .224 \\
\hline $\begin{array}{l}\text { 4. I turn off the lights and electrical machines when I am finished using } \\
\text { them. }\end{array}$ & .341 \\
\hline 5. When I find the garbage bin, I will put the waste in the bin. & .398 \\
\hline $\begin{array}{l}\text { 6. I helps reminding others to take care of the facilities in the house and } \\
\text { school. }\end{array}$ & .314 \\
\hline $\begin{array}{l}\text { 7. I offer to help in taking care of household chores without anyone having } \\
\text { to ask. }\end{array}$ & 361 \\
\hline 8. I am a patient and have respect for others. & .474 \\
\hline $\begin{array}{l}\text { 9. I take great care of the facilities around the house and school, making } \\
\text { sure they are clean and in a good condition. }\end{array}$ & .493 \\
\hline $\begin{array}{l}\text { 10. I share and let other members use the facilities/properties of the } \\
\text { house. }\end{array}$ & .471 \\
\hline
\end{tabular}

Table 1 displayed the reliability results in three dimensions. The highest one was students' motivation dimension (alpha $=.838$ ). The second dimension was students' behavior (alpha $=.811$ ) and students' awareness dimension was the third (alpha $=.791$ ).

Table 2. Correlation among study variables Correlations between major variables $(N=725)$

\begin{tabular}{|l|c|c|r|r|r|}
\hline & $\begin{array}{c}\text { Students' } \\
\text { Awareness }\end{array}$ & $\begin{array}{c}\text { Students' } \\
\text { Motivatio } \\
\mathrm{n}\end{array}$ & $\begin{array}{c}\text { Students' } \\
\text { Behavior }\end{array}$ & & \\
\hline Students' Awareness & & $.627^{* *}$ & $.653^{* *}$ & $.079^{*}$ & $.080^{*}$ \\
\hline Students' Motivation & & & $.520^{* *}$ & .019 & .067 \\
\hline Students' Behavior & & & & $.177^{* *}$ & $.097^{* *}$ \\
\hline
\end{tabular}




\begin{tabular}{|l|l|l|l|l|l|}
\hline Gender & & & & & $.260^{* *}$ \\
\hline GPA & & & & & \\
\hline${ }^{*} p<.05,{ }^{* *} p<.01$ & & & \\
\hline
\end{tabular}

The results from Table 2 showed the positive correlation between Students' Awareness, Students' Motivation and Students' Behavior. This correlation was significant at the .01 level. When we focused on gender, we found that the girls 'students with a higher GPA had more awareness than the boys at the .05 level, and they also have more behavior at the .01 level.

Table 3. Results from Pair Sample Test $t$-Value for dependent samples ( $N=125)$

\begin{tabular}{|l|c|c|c|c|c|c|}
\hline & $\begin{array}{c}\text { Pre-test } \\
\text { Mean }\end{array}$ & $\begin{array}{c}\text { Post-test } \\
\text { Mean }\end{array}$ & $\begin{array}{c}\text { Standard } \\
\text { Deviation }\end{array}$ & $t$-value & $\mathrm{df}$ & $p$ \\
\hline $\begin{array}{l}\text { Change in Civic minded } \\
\text { "awareness" }\end{array}$ & 3.76 & 3.95 & 0.27 & $7.83^{*}$ & 124 & .000 \\
\hline $\begin{array}{l}\text { Change in Civic minded } \\
\text { "motivation" }\end{array}$ & 3.47 & 3.66 & 0.24 & $8.85^{*}$ & 124 & .000 \\
\hline $\begin{array}{l}\text { Change in Civic minded } \\
\text { "behavior" }\end{array}$ & 3.67 & 3.93 & 0.27 & $10.85^{*}$ & 124 & .000 \\
\hline
\end{tabular}

This table showed dependent sample $t$-test results. The test-retest comparison showed significant gains in students' civic-mindedness, $(t=7.83, t=8.85, t=10.85, p<.001)$, providing further evidence of all scale construct validity (Cronbach \& Meehl ,1955 cited in Kane, M.,2012).

Table 4. Regression Analysis : Civic-Mindedness Values Predicting

\begin{tabular}{|l|l|l|l|l|}
\hline \multirow{2}{*}{ Outcome Variables } & \multirow{2}{*}{ Influence Variables } & \multicolumn{3}{|c|}{ Parameter } \\
\cline { 3 - 5 } & & $\boldsymbol{\beta}$ & $\boldsymbol{t}$ & $\boldsymbol{p}$ \\
\hline Change in Awareness & Gender & -.070 & -.740 & .461 \\
\hline & GPA & .077 & .812 & .418 \\
\hline Change in Motivation & Gender & .107 & 1.145 & .255 \\
& GPA & .110 & 1.175 & .242 \\
\hline Change in Behavior & Gender & -.215 & $-2.35^{*}$ & .02 \\
\cline { 2 - 5 } & GPA & -.112 & -1.23 & .22 \\
\hline
\end{tabular}

For change of awareness, adjusted $R^{2}=-.009, F=.467$. For change of motivation, adjusted $R^{2}=014$, $F=.467$. For change of behavior, adjusted $R^{2}=.057, F=4.781, p<.05$.

The results from this table demonstrated that the boys who participated in the process had a higher level of behavioral change at a 0.05 level.

\section{DISCUSSION AND CONCLUSIONS}

The findings of this study show the reliability, validity and positive correlation between a civic-mindedness in three components ("awareness", "motivation" and "behavior") when the elements are sorted in the order. We found that the highest element is motivation followed by behavior and awareness respectively. The significance of the correlation showed that if the civic-minded "awareness" increased, motivation and behavior will increase together. Each experience affects the subsequent one, as well as how one's awareness continues to increase. The ways children understand themselves through learning processes in school lead them through life and influence their choices in the future. Accordingly, developing learner identity is one of the goals teachers should achieve in schools. The study of self-awareness originates from psychologists' claims that the well-rounded self is of fundamental importance to one's Therefore, the children need to develop self-awareness in order to be more successful in school and later in their lives. Everyone has different abilities and limitations that construct the self and, by developing awareness of these components and of the environment one lives in, one achieves fulfillment of the self (Goleman, D., et.al, 2018).

In light of the above, when we focused on gender, the research found different significance. The girls and the higher GPA students had awareness and behavior more than the boys. The findings show the girls have more civic-mindedness, that in accordance with the findings the girl has more self-disciplined, 
and this advantage is more relevant to report card grades than to achievement or aptitude tests. (Peterson et. al., 2018) The findings from the research found significant changes in civic-minded "awareness", "motivation", and "behavior" among children after a year of contemplative educational experiences in school. Boys reported significantly more change in civic-minded "behavior" than girls. We discuss the implications of our findings for the cultivation of civic learning among children and educators alike.

\section{Implications}

The suggestion on the guided development of civic-mindedness among elementary school students could be concluded into 3 elements as follows:

\section{School}

- Schools and administrators should focus on the civic-mindedness building by establishing student's public mindedness building as a school's policy.

- Schools should integrate civic-mindedness in the school's curriculum or establish any additional course on civic-mindedness as well as create the principles of concrete measurement and evaluation for use as the guidelines for managing instruction of each learning area.

\section{Teacher}

- Teachers should manage instruction by facilitating and building civic-mindedness including: providing environment and atmosphere that facilitates student's learning, using and exemplifying a good model for inspiring students to learn, teaching students explicitly until it deeply affects the feelings and minds of the students thus stimulating, promoting, and training on how to use ethical reasonings, practicing thinking skills of students regularly via various methods as well as training them to use such skills regularly in order to develop their skills and reinforce good attitude. In addition, the teacher should teach things that are consistent with direct meaning to students helping to enable students to realize their own thinking and action as well as help them to practice to be ready to develop and improve themselves regularly.

The teacher should be a good model for students in all dimensions, especially responsibility on personal duties. For example, performing activities of morning ceremony. The teacher is able to promote the development of civic-mindedness of students by suggesting students to realize the value and importance of morning ceremony activities that help to foster students to pay respect and admire their nation, religion, and King. In addition, the teacher should practice students to be punctual with discipline and patience as well as to be a good listener with consideration on public benefits. The teacher should be the model in dressing cleanly and properly according to school's rules and regulations as well as upon appropriateness and occasion in order to practice students to see the model of social coexistence requiring students to pay respect to rules and regulations or cultures that are mutually created for giving pleasant coexistence. The teacher should be the model on going to school early in the morning and be punctual to teaching timetable in order to make students realize that every person has his/her own duties and they should perform their duties with the best of their ability.

The teacher should be able to create some activities for fostering civic-mindedness in students extensively in all learning areas by inserting some contents on civic-mindedness to activities. For example, maintaining health and hygiene (i.e., they should use a mask for covering their mouth and nose or they should go to see the doctor as soon as possible or stay at home in order to prevent infection and disease outbreak. This will help students practice to pay attention to effects that may affect other people due to their actions. The teacher should emphasize unity, sacrifice, kindness, hospitality, maintaining school's assets, economic sufficiency, not taking advantage of others, realizing the value of natural resources and environment, both the reduction and management of the school's garbage.

Teacher should mutually coordinate with parents closely to develop civic-mindedness of students. For example, attending the meeting with parents, praising and admiring students who are the model of performing public benefits, inviting parents to participate in activities of schools for public benefits. For example, religious activities, activities for promoting good interactions, etc.

\section{Parents}

Parents should participate in fostering civic-mindedness in children under the following guidelines:

Parents should spend their quality time with their children. For example, reading some books, doing housework, dining, watching television, relaxing and doing activities together, having good interaction, planning activity plans in advance. 
Parents should assign their children to be responsible and perceive the situation of family problems in order to practice their responsibilities before developing civic-mindedness.

Parents should cooperate with the school in developing civic-mindedness of children regularly. For example, attending the meeting and talking with class teachers to perceive the behaviors of students at home and school as well as support them to participate in activities for public benefits that are held by the school.

Parents should promote their children to participate in some activities of the community and society occasionally. For example, participating in cleaning the village, donating things to others, and making merit and public benefits in temples so that students practice to have public responsibility.

\section{REFERENCES}

Amanda Ie, Chhristelle T.Ngnoumen and Ellen J.Langer.(2014). The Wiley Blackwell Handbook of Mindfulness, John Wiley\& Sons, Ltd,Oxford.

Bailey,C.,Peterson, J.R., Schnegelsiepen, A., Stuebing, S.L.,\&Kirkpatrice,K.(2018). Durability and generalizability of time-based intervention effects on impulsive choice in rats. Behavioral Processes, $152,54-62$.

Burke, C.(2010). Mindfulness-Based Approaches with Children and Adolescents: A Preliminary Review of Current Research in an Emergent Field. Journal of Child and Family Studies, 19, 133-144.

Eisenberg, N., Eggum-Wilkens, N. D., \& Spinrad, T. L. (2015). The development of prosocial behavior. In D. A. Schroeder \& W. G. Graziano (Eds.), Oxford library of psychology.

The Oxford handbook of prosocial behavior (p. 114-136). Oxford University Press.

Eysenck, MW. (2015). AQA Psychology as and A-level Year 1, New York \& London : Psychology Press.

Fullan, M.,(2015). Leading Educational Change: Global Issues, Challenges, and Lessons on Whole-System Reform, New York \& London :Teachers College Press.

Gardner,H.,(2011). Frames of Mind: The Theory of Multiple Intelligences. New York : Hachette.

Goldstein,S., Naglieri,JA.,(2010) refer to Kohlberg,L.(1976). Encyclopedia of Child Behavior and Development. Utah: Springer Science\& Business Media.

Goleman, D., Kaplan, RS., David, S.,Eurich, T.,(2018) Self-Awareness (HBR Emotional Intelligence Series). USA: Harvard Business Review Press.

John, P., (2010). refer to Piaget, J. \& Inheldr,B.,(1969). The psychology of the child. New York : Basic books. Kane, M.,(2012). All Validity is construct validity. Or Is It? Measurement, 10:66-70. Psychology Press.

McCown, D. (2013). The Ethical Space of Mindfulness in Clinical Practice: An Exploratory

Essay. London :Jessica Kublishers. Mick, DG.,Pettigrew,S.,Pechmann,C.,Ozanne, JL.,(2012). Transformative Consumer Research for Personal and Collective Well-Being, New York : Taylor\& Francis Group,LLC.

Panna, K., (2016). Public Mindedness is easy to build. Bangkok: Chulalongkorn University Printing House.

Ponkam, D.(2012). Research and Development of Public Mind Enhancement Curriculum Based on Social Meliorism Theory for Elementary School Students, Thesis Ph.D. in Curriculum and Instruction, Chulalongkorn University.

Rakmanee, S.(2018). Forgotten Values of Thailand. Retrieved December 14, 2018, fromhttp://share.psu.ac.th/blog/pom-sec1/1132.

Smart, D., et al.(2020). "The development of civic mindedness." Australian Institute of Family Studies, Melbourne. Retrieved 28 April,2020, from https://www.researchgate.net/publication/292124642.

Srijumnong, S., Sri-ampai, P, and Chano, J.(2015). Developing public mind curriculum for lower secondary school classes using contemplative education methods. Educational Research and Review, 10(16), 2387-2399.

Tewanarumitkun,P.,(2012). Civic Education. Bangkok : Nanmee Books Publication.Lt.D.

Thomas,K.,(2017). Assessing Intellectual Property Compliance in Contemporary China: The World Trade Organisation TRIPS Agreement, Singapore: Springer copyright. Valdez, K.,(2020). How to Boost Your Self Confidence and Self Esteem for the Rest of Your Life and Become the Person you really want to be(Self-empowerment affirmations for improved self-esteem). Google play edition.

Visalo, P.(2018). Civic-mindedness. Retrieved 14 November, 2018, fromhttp://www.volunteerspirit.org/?q=node/203. 